Research Article

\title{
Comparison of AOPs Efficiencies on Phenolic Compounds Degradation
}

\section{Lourdes Hurtado, ${ }^{1}$ Deysi Amado-Piña, ${ }^{1}$ Gabriela Roa-Morales, ${ }^{1}$ Ever Peralta-Reyes, Eduardo Martin del Campo, ${ }^{3}$ and Reyna Natividad ${ }^{1}$}

\author{
${ }^{1}$ Chemical Engineering Lab, Centro Conjunto de Investigación en Química Sustentable, UAEMex-UNAM, \\ Universidad Autónoma del Estado de México, km 14.5 Toluca-Atlacomulco Road, 50200 Toluca, MEX, Mexico \\ ${ }^{2}$ Instituto de Ecología, Universidad del Mar, Ciudad Universitaria S/N, 70902 Puerto Ángel, OAX, Mexico \\ ${ }^{3}$ Chemical Engineering Department, Faculty of Chemistry, Universidad Autónoma del Estado de México, \\ Paseo Colon esq. Paseo Tollocan s/n, 50120 Toluca, MEX, Mexico
}

Correspondence should be addressed to Reyna Natividad; reynanr@gmail.com

Received 23 July 2016; Revised 11 October 2016; Accepted 20 October 2016

Academic Editor: Sedat Yurdakal

Copyright ( 92016 Lourdes Hurtado et al. This is an open access article distributed under the Creative Commons Attribution License, which permits unrestricted use, distribution, and reproduction in any medium, provided the original work is properly cited.

\begin{abstract}
In this work, a comparison of the performances of different AOPs in the phenol and 4-chlorophenol (4-CP) degradation at lab and pilot scale is presented. It was found that, in the degradation of phenol, the performance of a coupled electro-oxidation/ozonation process is superior to that observed by a photo-Fenton process. Phenol removal rate was determined to be $0.83 \mathrm{mg} \mathrm{L}^{-1} \mathrm{~min}^{-1}$ for the coupled process while the removal rate for photo-Fenton process was only $0.52 \mathrm{mg} \mathrm{L}^{-1} \mathrm{~min}^{-1}$. Regarding 4-CP degradation, the complete disappearance of the molecule was achieved and the efficiency decreasing order was as follows: coupled electrooxidation/ozonation $>$ electro-Fenton-like process $>$ photo-Fenton process $>$ heterogeneous photocatalysis. Total organic carbon was completely removed by the coupled electro-oxidation/ozonation process. Also, it was found that oxalic acid is the most recalcitrant by-product and limits the mineralization degree attained by the technologies not applying ozone. In addition, an analysis on the energy consumption per removed gram of TOC was conducted and it was concluded that the less energy consumption is achieved by the coupled electro-oxidation/ozonation process.
\end{abstract}

\section{Introduction}

Water detoxification is an important issue that demands the immediate development and implementation of effective technologies able to abate pollutants in industrial wastewater. While no strict regulation about industrial wastewater could be applied to reduce the amounts of dangerous chemicals incorporated into water, the alternative is to follow the remedial route for degradation of pollutants and research needs to be done in this sense [1-3]. Among the numerous pollutant species, phenol and its derivatives deserve special attention due to its extended use, high toxicity, and its resistance to complete mineralization. Phenol $\left(\mathrm{C}_{6} \mathrm{H}_{6} \mathrm{O}\right)$ is employed as a raw material in the synthesis of innumerable chemical products as dyes, resins, and pharmaceuticals $[4,5]$. One of the main phenol derivatives is $4-\mathrm{CP}$ that is also widely employed in different industries [6, 7]. Phenolic compounds exposed to environment without any control can result in its transformation to more dangerous degradation products. The conventional wastewater treatment methods (i.e., filtration, centrifugation, sedimentation, coagulation, and aerobic or anaerobic processes) do not represent a real option to completely eliminate toxic aromatic compounds. As alternative, the advanced oxidation processes (AOPs) have emerged and received special attention due to the possibility to be helpful in the transformation of organic compounds into carbon dioxide and water at moderate operation conditions by means of potent oxidant agents and low cost and widely available reagents [8-11]. These processes have been successfully applied to water treatment for phenolic compounds removal and some of them are Fenton [12], photo-Fenton [13], electro-Fenton [4], electro-Fenton-like [14], anodic oxidation 


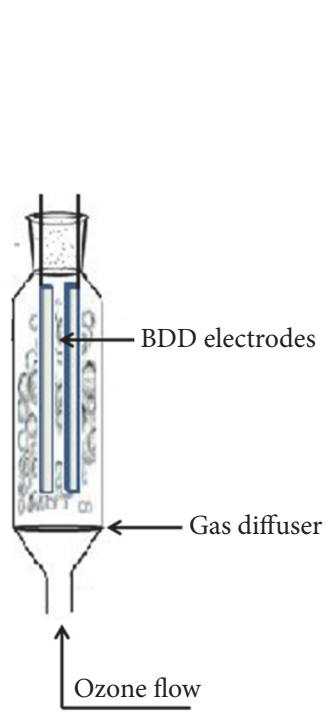

(a)

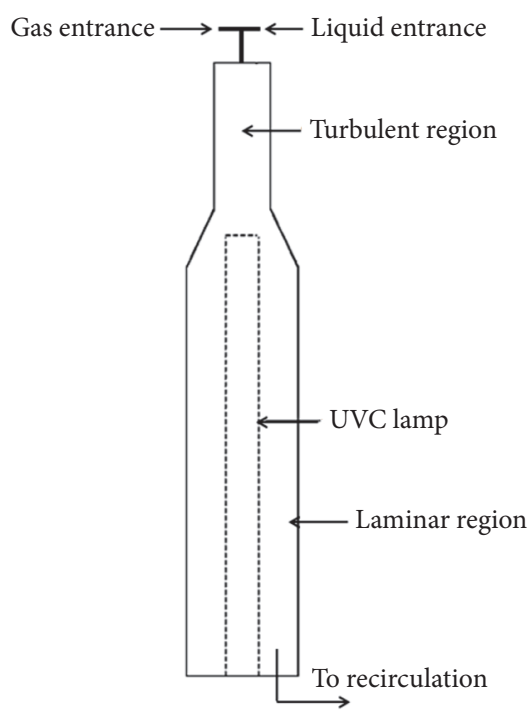

(b)

FIGURE 1: (a) Upflow bubble column reactor for coupled electro-oxidation/ozonation process. (b) Cocurrent downflow bubble column used for photocatalytic process for 4-CP degradation.

[15], photo-electro-Fenton [1], peroxicoagulation [16], $\mathrm{H}_{2} \mathrm{O}_{2}$ electrogenerated [17], photocatalysis [18], and ozonation [19] processes. Electrochemical oxidation is a promising clean technology that involves the production of hydroxyl radicals through anodic/cathodic reactions taking place at the electrodes $[9,11]$. Ozonation process is also considered as a potent and clean technology to mineralize organic matter [20]. Ozone toxicity at the levels employed for organic degradation processes can be considered as low. A Fenton process involves the use of $\mathrm{H}_{2} \mathrm{O}_{2}$ which also is considered as a nontoxic reagent due to its decomposition gives inert compounds as oxygen and water [21]. Metallic reagents $\left(\mathrm{Fe}^{2+} / \mathrm{Fe}^{3+}\right.$, $\left.\mathrm{Cu}^{2+} / \mathrm{Cu}^{+}\right)$are also low cost and wide availability materials to conduct Fenton and Fenton-like processes [1]. Heterogeneous photocatalysis involves the activation of chemical reactions by light and implies the use of semiconductors as catalyst which normally are prepared from cheap metals [22]. All the aforementioned processes can be operated under mild conditions (room temperature and atmospheric pressure) reducing energy consumption cost and giving priority to environmental safety. Despite the variety of AOPs, in this work we focus on the degradation of phenolic compounds (phenol and 4-chlorophenol) by the following technologies: coupled electro-oxidation/ozonation, photo-Fenton, photocatalysis, and electro-Fenton-like processes performed at lab and pilot scale. It is worth clarifying that the results presented here for every treatment were chosen as the best ones in terms of phenolic compound mineralization from a set of experiments that have been reported elsewhere [23-26] by our group. Therefore, this work mainly aims to identify the most promising technology among the studied ones by comparing them in terms of mineralization efficiency and energy consumption per removed gram of total organic carbon at the best conditions previously reported for each process.

\section{Materials and Methods}

2.1. Reagents. Phenol $\left(\mathrm{C}_{6} \mathrm{H}_{5} \mathrm{OH}\right)$ was purchased from Merck. Reagent grade 4-CP $\left(\mathrm{ClC}_{6} \mathrm{H}_{4} \mathrm{OH}\right)$ and 4-aminoantipyrine $\left(\mathrm{C}_{11} \mathrm{H}_{13} \mathrm{~N}_{3} \mathrm{O}\right)$ were purchased from Sigma-Aldrich. Solutions of phenolic compounds at different concentrations were prepared with deionized water. Potassium ferrocyanide $\left(\mathrm{C}_{6} \mathrm{~N}_{6} \mathrm{FeK}_{3}\right)$ was obtained from Baker. Hydrotalcite-like compound (MgAlZn 5\%) used as photocatalyst was prepared according to the procedure described in a previous work [24]. $\mathrm{H}_{2} \mathrm{O}_{2}$ solution was provided by Fermont (30.2\% purity).

\subsection{Phenolic Compounds Oxidation}

2.2.1. Coupled Electro-Oxidation/Ozonation. Oxidation of phenolic compounds by a coupled method was conducted in an upflow bubble column reactor adapted as electrochemical cell with two BDD (boron doped diamond) electrodes $(20 \mathrm{~cm}$ $\times 2.5 \mathrm{~cm}$ ) working as anode and cathode separated at a distance of $1 \mathrm{~cm}$. Figure 1 depicts a schematic representation of the reaction system. Superficial area of electrodes was equal to $50 \mathrm{~cm}^{2}$ and reaction volume was $1 \mathrm{~L}$ of solution. $0.1 \mathrm{M}$ $\mathrm{Na}_{2} \mathrm{SO}_{4}$ was employed as support electrolyte and the initial concentration of phenol/4-CP to be degraded was $100 \mathrm{ppm}$. Ozone was produced in a Pacific Ozone Technology ozone generator by electric discharge. The ozone concentration in the gas stream at the inlet of the reactor was determined to be $5 \pm 0.05 \mathrm{mg} \mathrm{L}^{-1}$. Gas was fed at a flowrate of $0.05 \mathrm{~L} \mathrm{~min}^{-1}$ rate and was continuously supplied to the reactor through a porous gas-plate diffuser placed at the bottom of the reactor. In a typical experiment the reactor was operated in batch mode regarding the liquid phase and it was performed at room temperature. In the case of phenol degradation a current density of $60 \mathrm{~mA} / \mathrm{cm}^{2}$ was applied to the BDD 
electrodes while $30 \mathrm{~mA} / \mathrm{cm}^{2}$ was the current density applied when 4-CP degradation was conducted. The applied potential value in this process was $11.25 \mathrm{~V}$. The results presented here were obtained with experiments where the $\mathrm{pH}$ was initially adjusted at 7.0 by means of $\mathrm{H}_{2} \mathrm{SO}_{4}$ and/or $\mathrm{NaOH}$ analytical grade. This $\mathrm{pH}$, in the range of 3 to 12 , was found to be the one maximizing the mineralization of the phenolic compounds. For the same reason the applied densities were selected. The whole set of results are to be published elsewhere [26]. Samples were analysed by UV-vis spectroscopy, HPLC, and TOC.

2.2.2. Photo-Fenton Process. Degradation of phenolic compounds aqueous solutions $\left(C_{0}=100 \mathrm{ppm}\right)$ was also performed by Photo-Fenton process in a jacketed Pyrex glass vessel of $0.1 \mathrm{~L}$ coupled with a UVP Pen-Ray lamp $(\lambda=254 \mathrm{~nm})$ located at its centre. Dimensions of the reactor were $2.5 \mathrm{~cm}$ internal diameter and $20 \mathrm{~cm}$ length. Iron reagent was provided through pillared iron clays at a catalyst concentration equal to $0.8 \mathrm{~kg} \mathrm{~m}^{-3}$. Further details about pillared iron clays preparation and reaction system operation can be consulted in Martin del Campo et al. [23]. A typical experiment was performed at room temperature. The initial $\mathrm{pH}$ value was adjusted at 2.8 at all experiments by means of $\mathrm{H}_{2} \mathrm{SO}_{4}$ addition since it is well known that photo-Fenton process performs the best at acidic conditions. A stoichiometric amount of $\mathrm{H}_{2} \mathrm{O}_{2}$ was added to the system. A control experiment to elucidate the interaction of hydrogen peroxide with phenol and 4-CP was conducted. The change concentration was less than $2 \%$ after 120 min even when an amount of 20 times the stoichiometric amount of hydrogen peroxide was added to a 4-CP aqueous solution. After studying the effect of initial hydrogen peroxide concentration and pillared clay loading, it was concluded [23] that the highest mineralization degree was attained when using the stoichiometric amount of hydrogen peroxide and $0.8 \mathrm{~g} \mathrm{~L}^{-1}$ of pillared clay. Therefore, the calculations presented here are those obtained with the results at such conditions. Samples were periodically withdrawn and analysed by UV-vis spectroscopy and with the TOC analyser.

2.2.3. Heterogeneous Photocatalysis. Photooxidation of 4$\mathrm{CP}\left(C_{0}=80 \mathrm{ppm}\right)$ was conducted at pilot scale in a cocurrent downflow bubble column (CDBC) in which $14 \mathrm{~L}$ of a contaminated solution was treated. This reactor was coupled with a HITECH NNI 400/147 XL UVC lamp $(\lambda=254 \mathrm{~nm})$ (Figure 1). A hydrotalcite-like compound ( $\mathrm{MgZnAl} 5 \%)$ was used as photocatalyst at a concentration equal to $1.2 \mathrm{~kg} \mathrm{~m}^{-3}$. According to the fabricant, the intensity of the light emitted by the employed lamp at a distance of $1 \mathrm{~m}$ is $1100 \mu \mathrm{W} \mathrm{cm}$. Temperature was kept constant during the entire experiment $(298 \mathrm{~K})$. pH was not adjusted at any moment of the experiment and basic conditions were observed at the end of it. In this case the effect of $\mathrm{pH}$ was not studied. Still, it is worth pointing out that hydrotalcites should not be used under acidic $\mathrm{pH}$ since get diluted. Further details about this device and its operation are available in Martin del Campo et al. [24]. The reaction was followed by UV-vis spectroscopy and TOC analysis.
2.2.4. Electro-Fenton-Like Process. This process was conducted in a cylindrical undivided electrochemical cell. Two pairs of electrodes were employed (the same material was used for anode and cathode). A pair of them made of graphite (superficial area: $50 \mathrm{~cm}^{2}$ ) was adapted for $\mathrm{H}_{2} \mathrm{O}_{2}$ electrogeneration in situ and two copper electrodes (superficial area: $50 \mathrm{~cm}^{2}$ ) were placed in order to provide, by applying pulses of current, metallic ions to catalyse the $\mathrm{H}_{2} \mathrm{O}_{2}$ dissociation (four $40 \mathrm{~mA} / \mathrm{cm}^{2}$ current pulses, 5 minutes each, every 30 minutes). Graphite electrodes were continuously energized with a current density of $4 \mathrm{~mA} / \mathrm{cm}^{2}$. The reaction volume was $0.85 \mathrm{~L}$ and consisted in a solution of $\mathrm{Na}_{2} \mathrm{SO}_{4}(0.05 \mathrm{M})$ and $4-\mathrm{CP}\left(C_{0}=100 \mathrm{ppm}\right)$. The applied potential value for this process was $8 \mathrm{~V}$. At all experiments, $\mathrm{pH}$ was adjusted at 3.0 and temperature was kept constant during the entire experiment $(291 \mathrm{~K})$. These conditions were found to provide the highest mineralization degree in a comprehensive study previously conducted [25]. In such a report the effect of several variables on mineralization degree was studied. These variables were type of $\mathrm{H}_{2} \mathrm{O}_{2}$ dissociation catalyst ( $\mathrm{Fe}$ or $\mathrm{Cu}$ ), oxygen flowrate, number and length of current pulses applied to iron or copper electrodes, and current density. Chemical analysis included both, HPLC and TOC analysis.

2.3. Chemical Analysis. Phenol absorbance measurements were performed in a Perkin Elmer Lambda 25 UV-vis spectrophotometer $(\lambda=510 \mathrm{~nm})$ by the reaction of phenol with 4 -aminoantipyrine in the presence of potassium ferricyanide 4 - $\mathrm{CP}$ concentration which was determined in the same device but the absorbance was taken at $\lambda=280 \mathrm{~nm}$. Mineralization of phenol and 4-CP solutions treated by the coupled $\mathrm{EO} / \mathrm{O}_{3}$ and EFL was quantified in a Shimadzu TOC- $\mathrm{L}_{\mathrm{CPN}}$ device. The samples from the PF and PC treatments were analysed in an Apollo Model 9000 TOC Analyser. The main reaction intermediates were identified and quantified by HPLC in a Waters 1015 equipment operating in isocratic mode. For the analysis of carboxylic acids, an Eclipse XDB C18 column was employed and the mobile phase $\left(0.6 \mathrm{~mL} \mathrm{~min}^{-1}\right)$ was composed of water : acetonitrile : phosphoric acid in an $89.9: 10: 0.1$ ratio. In the case of aromatic by-products, the chemical analysis required an Ascentis C18 column and a mobile phase $\left(1 \mathrm{~mL} \mathrm{~min}^{-1}\right)$ composed of methanol: water in an $80: 20$ ratio acidified by $5 \mathrm{mM}$ of $\mathrm{H}_{2} \mathrm{SO}_{4}$. The UV detector was configured at $210 \mathrm{~nm}$ to quantify carboxylic acids and at $280 \mathrm{~nm}$ to quantify aromatic compounds.

\section{Results and Discussion}

3.1. Phenol Degradation. Degradation of phenol was performed by two different AOPs: coupled electro-oxidation/ ozonation process $\left(\mathrm{EO} / \mathrm{O}_{3}\right)$ and photo-Fenton process $(\mathrm{PF})$. These processes were evaluated after $60 \mathrm{~min}$ of treatment. It was found that the coupled treatment reached $100 \%$ of phenol degradation while by PF it was less efficient with only $36 \%$ of degradation of initial phenol and increased to $67 \%$ after $120 \mathrm{~min}$. Furthermore, it is worth noticing that the reaction volume in the coupled $\mathrm{EO} / \mathrm{O}_{3}$ is about 10 times higher than that treated by photo-Fenton process. 
The superior performance of the coupled process is expected since the synergetic effect of two coupled AOPs accelerates the degradation of the model compound. If the reaction time in photo-Fenton process was extended, probably the same degradation as that with the coupled process could be achieved.

The common element in the aforementioned processes is the oxidation of phenol molecule by means of hydroxyl radical according to (1)-(2) for EO [27], (3) for ozonation [27], and (4) for photo-Fenton process [11]. Oxidation through electrochemical process can follow two routes depending on the oxidizing agent: by hydroxyl radical produced by anodic oxidation (see (1)) or by hydrogen peroxide produced by cathodic reduction (see (2)). In ozonation two degradation routes can also be distinguished, direct oxidation of organic compounds due to the electrophilic character of $\mathrm{O}_{3}$ and indirect oxidation by production of hydroxyl radicals (see (3)) although at a $\mathrm{pH}$ of 7 no preference for direct or indirect oxidation has been reported [27]. Finally, in photo-Fenton process the hydroxyl radical is produced by interaction of peroxide with light and iron reagent (see (4))

$$
\begin{aligned}
\mathrm{BDD}+\mathrm{H}_{2} \mathrm{O} & \longrightarrow \mathrm{BDD}\left({ }^{\circ} \mathrm{OH}\right)+\mathrm{H}^{+}+\mathrm{e}^{-} \\
\mathrm{O}_{2}+2 \mathrm{H}^{+}+2 \mathrm{e}^{-} & \longrightarrow \mathrm{H}_{2} \mathrm{O}_{2} \\
2 \mathrm{O}_{3}+\mathrm{H}_{2} \mathrm{O} & \longrightarrow 2 \mathrm{HO}^{\bullet}+2 \mathrm{O}_{2}+\mathrm{HO}_{2} \\
\mathrm{H}_{2} \mathrm{O}_{2}+\mathrm{Fe}^{2+}+h \nu & \longrightarrow \mathrm{Fe}^{3+}+\mathrm{HO}^{-}+\mathrm{HO}^{\bullet}
\end{aligned}
$$

After hydrogen peroxide or hydroxyl radical is produced, this species reacts with phenol molecule oxidizing it towards intermediates or directly to carbon dioxide and water:

$$
\begin{array}{r}
\mathrm{R}+\text { Phenol } \longrightarrow \text { Intermediates } \longrightarrow \mathrm{CO}_{2}+\mathrm{H}_{2} \mathrm{O} \\
\mathrm{R}={ }^{\cdot} \mathrm{OH} \text { or } \mathrm{H}_{2} \mathrm{O}_{2}
\end{array}
$$

Due to the single or multiple possible degradation pathways for each treatment, differences in the concentration profiles as well as in the mineralization of the molecule were expected. This fact was confirmed and Figure 2 depicts normalized phenol concentration profiles of two representatives study cases: coupled $\mathrm{EO} / \mathrm{O}_{3}$ and photo-Fenton processes.

As expected, degradation routes of $\mathrm{EO} / \mathrm{O}_{3}$ and $\mathrm{PF}$ exhibit important differences. Degradation rate is considerably slower in the latter process which may require excessive reaction time to achieve competitive results against other technologies. Phenol degradation rate was determined as function of the total organic carbon (TOC) decay in the coupled $\mathrm{EO} / \mathrm{O}_{3}$. Thus, for this system,

$$
-r_{\mathrm{TOC}}=1.3501(\mathrm{mg} \mathrm{TOC} / \mathrm{L} \mathrm{min}) \text {. }
$$

The use of the Mineralization Current Efficiency for the comparison of the performances of electrochemical processes is widely accepted. In our case and on the basis of total organic carbon measurements, we also introduce this parameter according to the equation proposed by Professor Brillas' group [28] which is presented below:

$$
\mathrm{MCE}=\frac{n F V(\text { Initial TOC }- \text { Final TOC })}{4.23 * 10^{7} \mathrm{mIt}} * 100,
$$

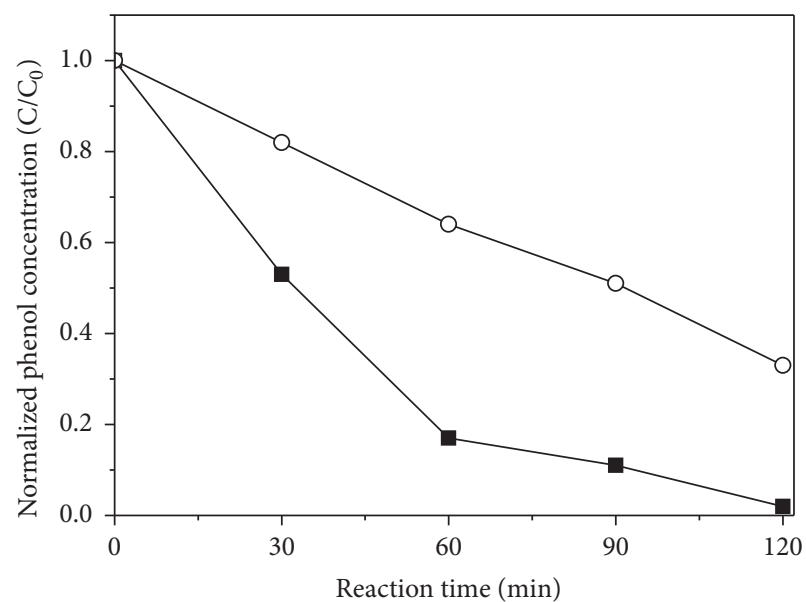

Figure 2: Phenol concentration temporal evolution obtained by $\mathrm{EO} / \mathrm{O}_{3}(\boldsymbol{\square})$ and photo-Fenton $(\mathrm{O})$ processes. Reaction conditions: EO $\left(j=60 \mathrm{~mA} \mathrm{~cm}^{-2} ; \mathrm{pH}=7\right)$; photo-Fenton $\left(C_{\text {cat }}=0.8 \mathrm{~kg} \mathrm{~m}^{-3} ; \mathrm{pH}\right.$ $=2.8)$.

where $n$ is number of consumed electrons, $F$ is Faraday constant $\left(96487 \mathrm{C} \mathrm{mol}^{-1}\right), V$ is electrolyte volume (L), TOC is total organic carbon $\left(\mathrm{mg} \mathrm{L}^{-1}\right), m$ is number of carbon atoms in the phenolic molecule (6), $I$ is current (A), and $t$ is time (h).

For phenol degradation $\left(\mathrm{C}_{6} \mathrm{H}_{6} \mathrm{O}\right), n=28$ according to the following chemical equation:

$$
\mathrm{C}_{6} \mathrm{H}_{6} \mathrm{O}+28 \mathrm{OH}^{-} \longrightarrow 6 \mathrm{CO}_{2}+17 \mathrm{H}_{2} \mathrm{O}+28 \mathrm{e}^{-}
$$

Finally, we calculate the MCE for the coupled $\mathrm{EO} / \mathrm{O}_{3}$ and results are presented in Table 1 .

As the final step of the phenol degradation study, the byproducts generated in the coupled $\mathrm{EO} / \mathrm{O}_{3}$ were identified. It was found that, in the first $10 \mathrm{~min}$ of treatment, aromatic compounds (hydroquinone, benzoquinone, and catechol) are formed and after $120 \mathrm{~min}$ practically they have disappeared by its degradation to carboxylic acids (oxalic, maleic, succinic, fumaric, and formic). Table 2 summarizes the identified byproducts as well as its retention times and concentrations after 10 minutes (aromatic compounds) and 20 minutes (carboxylic acids) for the $\mathrm{EO} / \mathrm{O}_{3}$ coupled process.

3.2. 4-CP Degradation. The second phenolic compound to be degraded by AOPs was 4 -CP. This molecule was elected to assess the performance of heterogeneous photocatalysis catalysed by $\mathrm{MgAlZn}$ 5\% hydrotalcite-like compound (PC: MgAlZn 5\%) and photo-Fenton process (PF) and ElectroFenton-like process (EFL) in which $\mathrm{H}_{2} \mathrm{O}_{2}$ is also electrogenerated in situ and coupled electro-oxidation/ozonation process $\left(\mathrm{EO} / \mathrm{O}_{3}\right)$. The response variables for comparison among the four treatments were molecule degradation followed by UV-vis spectroscopy and mineralization degree by TOC analysis. For the former case the time evolution of 4-CP is presented in Figure 3 during a 180 min period.

From this concentration profiles comparison, we can observe important differences among AOPs. The total degradation of the model molecule is reached by both, EFL and 
TABLE 1: MCE for the phenol degradation by coupled $\mathrm{EO} / \mathrm{O}_{3}$ process.

\begin{tabular}{lccc}
\hline $\begin{array}{l}\mathrm{TOC}_{t=0} \\
\left(\mathrm{mg} \mathrm{TOC} \mathrm{L}^{-1}\right)\end{array}$ & $\begin{array}{c}\mathrm{TOC}_{t=2 \mathrm{~h}} \\
\left(\mathrm{mg} \mathrm{TOC} \mathrm{L}^{-1}\right)\end{array}$ & $\begin{array}{c}j \\
\left(\mathrm{~mA} \mathrm{~cm}^{-2}\right)\end{array}$ & $\begin{array}{c}\text { MCE } \\
(\%)\end{array}$ \\
\hline 82.3 & 0.14 & 60 & 14.3 \\
\hline
\end{tabular}

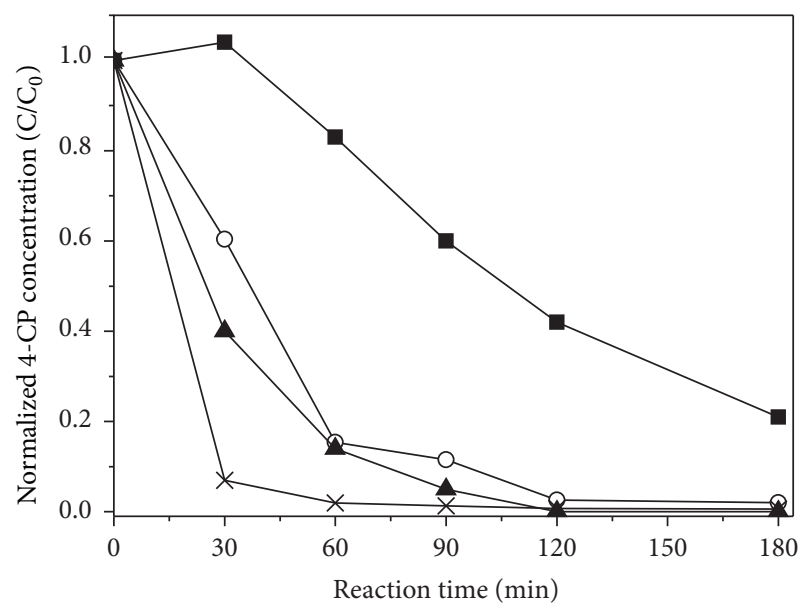

FIgURE 3: Temporal evolution of 4-CP concentration obtained by the following treatments: PC: MgZnAl 5\% (ם), PF (O), EFL (ム), and $\mathrm{EO} / \mathrm{O}_{3}(\times)$. Reaction conditions: EFL ( $j$ at copper electrodes $=40 \mathrm{~mA} \mathrm{~cm}^{-2}, j$ at graphite electrodes $=4 \mathrm{~mA} \mathrm{~cm}^{-2}$, and $C_{0}=$ $100 \mathrm{ppm}) ; \mathrm{PC}\left(C_{\mathrm{Cat}}=1.2 \mathrm{~kg} \mathrm{~m}^{-3} ; C_{0}=80 \mathrm{ppm}\right) ; \mathrm{PF}\left(C_{\mathrm{Cat}}=\right.$ $\left.0.8 \mathrm{~kg} \mathrm{~m}^{-3} ; C_{0}=100 \mathrm{ppm}\right) ; \mathrm{EO} / \mathrm{O}_{3}\left(j=30 \mathrm{~mA} \mathrm{~cm}^{-2} ; C_{0}=\right.$ $100 \mathrm{ppm})$.

$\mathrm{EO} / \mathrm{O}_{3}$ treatments, and it can be observed that since $120 \mathrm{~min}$ no signal of 4-CP was detected. By means of PF almost the total degradation is attained. If we contrast these results with those obtained for phenol degradation, the $\mathrm{Cl}^{-}$substituent present in 4-CP molecule appears to favour degradation process as has been reported by Pera-Titus and coworkers [11]. Photocatalytic process also was successfully applied to 4-CP degradation although no complete degradation was attained in $180 \mathrm{~min}$. The perception that no degradation is occurring in $\mathrm{PC}$ process during the first $30 \mathrm{~min}$ can be explained by an electronic effect that modifies the UV absorbance spectrum and already has been reported in photocatalytic process as a photoinduced period associated with reactions that imply free-radicals formation [29]. It is beyond the scope of this work to explore the effect of variables like catalyst concentration or light intensity among others but further details of this process can be consulted in Martin del Campo et al. [24].

The following chemical reactions (see (9)-(15)) are intended to explain the different performance obtained by employing the referred processes in the 4-CP degradation. Coupled $\mathrm{EO} / \mathrm{O}_{3}$ involved reactions have been previously presented (see (1)-(3)). Regarding photocatalytic process, it starts with the excitation of a semiconductor, giving place to the generation of hole-electron pairs (see (9)) that are the precursors for hydroxyl radical formation (see (10)). This radical species can directly oxidize organic matter (see (5)) or also form hydrogen peroxide (see (11)) that also decomposes to hydroxyl radical (see (12)) [24, 30]. Hydroxyl radical formed by any pathway reacts with organic matter producing intermediates that could be finally oxidized to carbon dioxide and water. For EFL treatment, the reactions involved in the production of hydroxyl radical are given by (13)-(14) [25]. It must be noticed that in this case the hydrogen peroxide required in (14) is in situ produced. Finally, photo-Fenton process also requires the generation of hydroxyl radicals and (15) illustrates this interaction [11]

$$
\begin{aligned}
\mathrm{TiO}_{2}+h v & \longrightarrow \mathrm{TiO}_{2}\left(\mathrm{e}^{-}+\mathrm{h}^{+}\right) \\
\mathrm{TiO}_{2} \mathrm{~h}^{+}+\mathrm{OH}^{-} \text {ad } & \longrightarrow \mathrm{TiO}_{2}+{ }^{\circ} \mathrm{OH} \\
\left(\mathrm{HO}^{\bullet}\right)_{2}+\left(\mathrm{HO}^{\bullet}\right)_{2} & \longrightarrow \mathrm{H}_{2} \mathrm{O}_{2}+\mathrm{O}_{2} \\
\mathrm{H}_{2} \mathrm{O}_{2}+\mathrm{e}^{-} & \longrightarrow{ }^{\bullet} \mathrm{OH}+\mathrm{OH}^{-} \\
\mathrm{Cu}^{2+}+\mathrm{e}^{-} & \longrightarrow \mathrm{Cu}^{+} \\
\mathrm{Cu}^{+}+\mathrm{H}_{2} \mathrm{O}_{2} & \longrightarrow \mathrm{Cu}^{2+}+\mathrm{OH}^{-}+{ }^{\circ} \mathrm{OH} \\
\mathrm{H}_{2} \mathrm{O}_{2}+\mathrm{Fe}^{2+}+h \nu & \longrightarrow \mathrm{Fe}^{3+}+\mathrm{HO}^{-}+\mathrm{HO}^{\bullet}
\end{aligned}
$$

If one compares the complexities of the hydroxyl radical production pathway by $\mathrm{EO} / \mathrm{O}_{3}, \mathrm{EFL}, \mathrm{PC}$, and $\mathrm{PF}$, it is clear that, in EFL and PF, radical production is beneficiated by the continuous regeneration of copper and iron species, respectively. By coupling $\mathrm{EO} / \mathrm{O}_{3}$, the total degradation is quickly reached and may be ascribed to the different noncompetitive pathways whereby hydroxyl radical is produced. In contrast, in the photocatalytic process, it is not possible to control the selectivity of hydroxyl radical to perform direct oxidation in addition to troubles related to hole-electron pair recombination.

As a complementary step of the comparison procedure, TOC analysis was conducted to establish the mineralization degree attained by the different methods as well as energy consumption required to mineralize one gram of total organic carbon. This parameter was calculated as follows [28]:

$$
\mathrm{EC}\left(\mathrm{kWh}_{\mathrm{TOC}}^{-1}\right)=\frac{E_{\text {cell }} I t}{V(\text { Initial TOC }- \text { Final TOC })},
$$

where $E_{\text {cell }}$ is voltage applied to the cell, $V$ is electrolyte volume (L), TOC is total organic carbon $\left(\mathrm{mg} \mathrm{L}^{-1}\right), I$ is current (A), and $t$ is time (h).

Figure 4 shows the results corresponding to mineralization rate and energy consumption on the basis of TOC removal by every assessed treatment, that is, $\mathrm{EO} / \mathrm{O}_{3}, \mathrm{EFL}, \mathrm{PC}$, and PF.

Total mineralization was only achieved by the coupled $\mathrm{EO} / \mathrm{O}_{3}$ after $100 \mathrm{~min}$ of treatment. In the studied treatment time, none of the other technologies were able to transform the whole organic matter to carbon dioxide and water which is a reminder of the well-known persistence of the 4-CP by-products generated through AOPs. In Figure 4, it is also worth noticing that interesting enough the process offering the less energy consumption is the coupled process $\mathrm{EO} / \mathrm{O}_{3}$. Furthermore, the calculated value suggests the process can 
TABLE 2: Concentration and retention time of by-products of the phenol oxidation in a $\mathrm{EO} / \mathrm{O}_{3}$ coupled process.

\begin{tabular}{lccc}
\hline & By-product & $\begin{array}{c}\text { Retention time } \\
(\mathrm{min})\end{array}$ & $\begin{array}{c}\text { Concentration } \\
(\mathrm{ppm})\end{array}$ \\
\hline \multirow{2}{*}{$\begin{array}{l}\text { Aromatic by-products after } \\
10 \text { min of treatment }\end{array}$} & Benzoquinone & 0.961 & 18 \\
& Catechol & 1.228 & 30 \\
& Hydroquinone & 4.988 & 1 \\
\hline & Oxalic & 2.222 & 8.5 \\
Carboxylic by-products after & Formic & 2.638 & 6 \\
20 min of treatment & Maleic & 3.121 & 7 \\
& Succinic & 3.332 & 5 \\
& Fumaric & 3.588 & 2 \\
\hline
\end{tabular}

TABLE 3: Calculation of MCE for the 4-CP degradation by electrochemical processes.

\begin{tabular}{lcccrr}
\hline Process & $\begin{array}{c}\text { TOC }_{t=0} \\
\left(\mathrm{mg} \mathrm{TOC} \mathrm{L}^{-1}\right)\end{array}$ & $\begin{array}{c}\text { TOC }_{t=2 \mathrm{~h}} \\
\left(\mathrm{mg} \mathrm{TOC} \mathrm{L}^{-1}\right)\end{array}$ & $\begin{array}{c}t \\
(\mathrm{~h})\end{array}$ & $\begin{array}{c}j \\
\left(\mathrm{~mA} \mathrm{~cm}^{-2}\right)\end{array}$ & $\begin{array}{c}\mathrm{MCE}^{2} \\
(\%)\end{array}$ \\
\hline Coupled EO/O & 59.37 & 0 & 1.5 & 30 & 23 \\
EFL & 64 & 19.2 & 2 & 40 & 92 \\
\hline
\end{tabular}

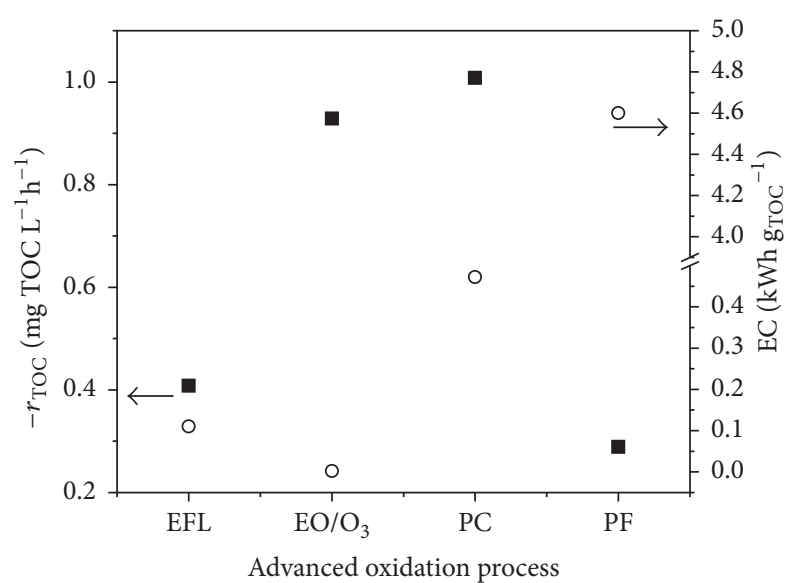

FIGURE 4: Mineralization rate of 4-CP molecule and energy consumption by $\mathrm{EFL}, \mathrm{EO} / \mathrm{O}_{3}, \mathrm{PC}: \mathrm{MgZnAl} 5 \%$, and $\mathrm{PF}$. Reaction conditions: $\operatorname{EFL}\left(j=40 \mathrm{~mA} \mathrm{~cm}{ }^{-2} ; \mathrm{TOC}_{0}=64 \mathrm{ppm}\right) ; \mathrm{PC}\left(C_{\mathrm{Cat}}=\right.$ $\left.1.2 \mathrm{~kg} \mathrm{~m}^{-3} ; \mathrm{TOC}_{0}=56 \mathrm{ppm}\right) ; \mathrm{PF}\left(C_{\mathrm{Cat}}=0.8 \mathrm{~kg} \mathrm{~m}^{-3} ; \mathrm{TOC}_{0}=\right.$ $70 \mathrm{ppm}) ; \mathrm{EO} / \mathrm{O}_{3}\left(j=30 \mathrm{~mA} \mathrm{~cm}{ }^{-2} ; \mathrm{TOC}_{0}=59 \mathrm{ppm}\right)$.

be conducted aided by solar cells which could considerably reduce the cost of the process. Also, from Figure 4, it can be concluded that the cocurrent downflow bubble column reactor is a promising technology that might be worthy to asses as electrochemical reactor to conduct the coupled process $\left(\mathrm{EO} / \mathrm{O}_{3}\right)$ with the additional advantage of reducing the waste of ozone.

Analogous to phenol degradation, the MCE was determined for the electrochemical processes (coupled $\mathrm{EO} / \mathrm{O}_{3}$ and $\mathrm{EFL}$ ) according to the following reaction:

$$
\begin{gathered}
\mathrm{ClC}_{6} \mathrm{H}_{4} \mathrm{OH}+27 \mathrm{OH}^{-} \longrightarrow \\
6 \mathrm{CO}_{2}+\mathrm{Cl}^{-}+16 \mathrm{H}_{2} \mathrm{O}+26 \mathrm{e}^{-}
\end{gathered}
$$

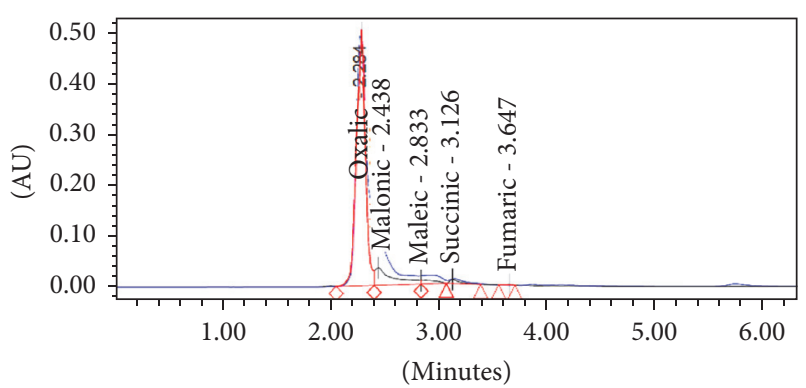

Figure 5: Chromatogram of 4-CP degradation by-products after 30 min of EFL treatment.

Results about MCE for electrochemical processes are presented in Table 3.

The efficiency of the coupled process is lower than the obtained for the EFL which almost reaches $100 \%$ of efficiency. It is worth clarifying that, in the case of EFL, the used current density to calculate MCE was the one applied to the graphite electrodes which was one order of magnitude lower than the one applied to the BDD in the coupled process.

Although by EFL and PF the model molecule was apparently destroyed (see Figure 3), it was only converted to smaller compounds that cannot be completely mineralized by the process and this implies the necessity to perform a post-treatment to reach a higher mineralization. Study of the recalcitrant by-products responsible of the partial mineralization was the final step of this work. This study was performed only for EFL. The side products of 4-CF degradation presents after $30 \mathrm{~min}$ of treatment were oxalic, malonic, maleic, succinic, and fumaric acids and Figure 5 exhibits a typical chromatograph in which all of them were identified at the referred time. Oxalic acid was present in higher amount and after $120 \mathrm{~min}$ was not possible to mineralize it by EFL. In contrast to phenol degradation, here only hydroquinone was detected as aromatic intermediate. 
Stability of oxalic acid appears to be the major obstacle to perform a complete mineralization of a phenolic compound. Further research in this sense should be conducted. Still, it is expected that the results presented in this work help to improve the existing knowledge in degradation processes of phenolic compounds through different AOPs.

\section{Conclusions}

Phenol degradation and 4-CP degradation by different advanced oxidation processes were conducted and compared. Important differences in efficiency and in energy consumption were found. Among the studied AOPs, the process that fully mineralizes both phenolic compounds is the coupled electro-oxidation/ozonation process. By this treatment, $100 \%$ degradation of phenol is achieved in only $60 \mathrm{~min}$ while TOC is removed at a rate of $1.3501 \mathrm{mg} \mathrm{TOC} \mathrm{L}^{-1} \mathrm{~min}^{-1}$. A complete mineralization is achieved after $100 \mathrm{~min}$. 4-CP is totally degraded and mineralized also by the coupled method although the highest TOC removal rate was found with the photocatalytic process $\left(\sim 1.0 \mathrm{mg} \mathrm{TOC} \mathrm{L}^{-1} \mathrm{~min}^{-1}\right)$ performed at pilot scale. Photo-Fenton with pillared clays was found to be the less efficient process among the studied ones. In terms of energy consumption, the coupled process outperforms the other ones since it exhibited the lowest energy consumption level. Still, the cocurrent downflow contactor reactor emerges as a promising technology to conduct advanced oxidation processes.

\section{Competing Interests}

The authors declare that they have no competing interests.

\section{Acknowledgments}

The authors are grateful to CONACYT for financial support through Project 168305. Lourdes Hurtado is grateful to CONACYT for Scholarship no. 24012. The technical support of Citlalit Soto is also acknowledged.

\section{References}

[1] P. V. Nidheesh and R. Gandhimathi, "Trends in electro-Fenton process for water and wastewater treatment: an overview," Desalination, vol. 299, pp. 1-15, 2012.

[2] C. Comninellis, A. Kapalka, S. Malato, S. A. Parsons, I. Poulios, and D. Mantzavinos, "Advanced oxidation processes for water treatment: advances and trends for R\&D," Journal of Chemical Technology \& Biotechnology, vol. 83, no. 6, pp. 769-776, 2008.

[3] V. K. Gupta, I. Ali, T. A. Saleh, A. Nayak, and S. Agarwal, "Chemical treatment technologies for waste-water recyclingan overview," RSC Advances, vol. 2, no. 16, pp. 6380-6388, 2012.

[4] A. Babuponnusami and K. Muthukumar, "Advanced oxidation of phenol: a comparison between Fenton, electro-Fenton, sonoelectro-Fenton and photo-electro-Fenton processes," Chemical Engineering Journal, vol. 183, pp. 1-9, 2012.

[5] G. Hurwitz, P. Pornwongthong, S. Mahendra, and E. M. V. Hoek, "Degradation of phenol by synergistic chlorineenhanced photo-assisted electrochemical oxidation," Chemical Engineering Journal, vol. 240, pp. 235-243, 2014.
[6] X. Liu, J.-H. Fan, and L.-M. Ma, "Elimination of 4-chlorophenol in aqueous solution by the bimetallic $\mathrm{Al}-\mathrm{Fe} / \mathrm{O}_{2}$ at normal temperature and pressure," Chemical Engineering Journal, vol. 236, pp. 274-284, 2014.

[7] A. Karci, "Degradation of chlorophenols and alkylphenol ethoxylates, two representative textile chemicals, in water by advanced oxidation processes: the state of the art on transformation products and toxicity," Chemosphere, vol. 99, pp. 1-18, 2014.

[8] M. A. Oturan and J.-J. Aaron, "Advanced oxidation processes in water/wastewater treatment: principles and applications. A review," Critical Reviews in Environmental Science and Technology, vol. 44, no. 23, pp. 2577-2641, 2014.

[9] C. A. Martínez-Huitle and S. Ferro, "Electrochemical oxidation of organic pollutants for the wastewater treatment: direct and indirect processes," Chemical Society Reviews, vol. 35, no. 12, pp. 1324-1340, 2006.

[10] J. M. Poyatos, M. M. Muñio, M. C. Almecija, J. C. Torres, E. Hontoria, and F. Osorio, "Advanced oxidation processes for wastewater treatment: state of the art," Water, Air, and Soil Pollution, vol. 205, no. 1-4, pp. 187-204, 2010.

[11] M. Pera-Titus, V. García-Molina, M. A. Baños, J. Giménez, and S. Esplugas, "Degradation of chlorophenols by means of advanced oxidation processes: A general review," Applied Catalysis B: Environmental, vol. 47, no. 4, pp. 219-256, 2004.

[12] A. Babuponnusami and K. Muthukumar, "A review on Fenton and improvements to the Fenton process for wastewater treatment," Journal of Environmental Chemical Engineering, vol. 2, no. 1, pp. 557-572, 2014.

[13] C. Catrinescu, D. Arsene, P. Apopei, and C. Teodosiu, "Degradation of 4-chlorophenol from wastewater through heterogeneous Fenton and photo-Fenton process, catalyzed by Al-Fe PILC," Applied Clay Science, vol. 58, pp. 96-101, 2012.

[14] M. Munoz, Z. M. De Pedro, G. Pliego, J. A. Casas, and J. J. Rodriguez, "Chlorinated byproducts from the fenton-like oxidation of polychlorinated phenols," Industrial and Engineering Chemistry Research, vol. 51, no. 40, pp. 13092-13099, 2012.

[15] E. Brillas, R. Sauleda, and J. Casado, "Degradation of 4-chlorophenol by anodic oxidation, electro-fenton, photoelectrofenton, and peroxi-coagulation processes," Journal of the Electrochemical Society, vol. 145, no. 3, pp. 759-765, 1998.

[16] S. Vasudevan, "An efficient removal of phenol from water by peroxi-electrocoagulation processes," Journal of Water Process Engineering, vol. 2, pp. 53-57, 2014.

[17] S.-H. Cho, A. Jang, P. L. Bishop, and S.-H. Moon, "Kinetics determination of electrogenerated hydrogen peroxide $\left(\mathrm{H}_{2} \mathrm{O}_{2}\right)$ using carbon fiber microelectrode in electroenzymatic degradation of phenolic compounds," Journal of Hazardous Materials, vol. 175, no. 1-3, pp. 253-257, 2010.

[18] K. Elghniji, O. Hentati, N. Mlaik, A. Mahfoudh, and M. Ksibi, "Photocatalytic degradation of 4-chlorophenol under Pmodified $\mathrm{TiO}_{2} / \mathrm{UV}$ system: kinetics, intermediates, phytotoxicity and acute toxicity," Journal of Environmental Sciences, vol. 24, no. 3, pp. 479-487, 2012.

[19] P. Van Aken, R. Van den Broeck, J. Degrève, and R. Dewil, “The effect of ozonation on the toxicity and biodegradability of 2,4dichlorophenol-containing wastewater," Chemical Engineering Journal, vol. 280, pp. 728-736, 2015.

[20] W. H. Glaze, J.-W. Kang, and D. H. Chapin, "The chemistry of water treatment processes involving Ozone, hydrogen peroxide and ultraviolet radiation," Ozone: Science \& Engineering, vol. 9, no. 4, pp. 335-352, 1987. 
[21] R. Bauer, G. Waldner, H. Fallmann et al., "The photo-fenton reaction and the $\mathrm{TiO}_{2} / \mathrm{UV}$ process for waste water treatmentnovel developments," Catalysis Today, vol. 53, no. 1, pp. 131-144, 1999.

[22] A. Di Paola, E. García-López, G. Marcì, and L. Palmisano, "A survey of photocatalytic materials for environmental remediation," Journal of Hazardous Materials, vol. 211-212, pp. 3-29, 2012.

[23] E. Martin del Campo, R. Romero, G. Roa, E. Peralta-Reyes, J. Espino-Valencia, and R. Natividad, "Photo-Fenton oxidation of phenolic compounds catalyzed by iron-PILC," Fuel, vol. 138, pp. 149-155, 2014.

[24] E. Martín del Campo, J. S. Valente, T. Pavón, R. Romero, Á. Mantilla, and R. Natividad, "4-Chlorophenol oxidation photocatalyzed by a calcined Mg-Al-Zn layered double hydroxide in a co-current downflow bubble column," Industrial \& Engineering Chemistry Research, vol. 50, no. 20, pp. 11544-11552, 2011.

[25] G. Santana-Martínez, G. Roa-Morales, E. Martin del Campo, R. Romero, B. A. Frontana-Uribe, and R. Natividad, "ElectroFenton and Electro-Fenton-like with in situ electrogeneration of $\mathrm{H}_{2} \mathrm{O}_{2}$ and catalyst applied to 4-chlorophenol mineralization," Electrochimica Acta, vol. 195, pp. 246-256, 2016.

[26] D. Amado-Piña, G. Roa-Morales, C. Barrera-Díaz et al., "Synergic effect of ozonation and electrochemical methods on oxidation and toxicity reduction: phenol degradation," Fuel, 2015.

[27] C. Qiu, S. Yuan, X. Li et al., "Investigation of the synergistic effects for $\mathrm{p}$-nitrophenol mineralization by a combined process of ozonation and electrolysis using a boron-doped diamond anode," Journal of Hazardous Materials, vol. 280, pp. 644-653, 2014.

[28] E. Brillas, I. Sirés, and M. A. Oturan, "Electro-fenton process and related electrochemical technologies based on fenton's reaction chemistry," Chemical Reviews, vol. 109, no. 12, pp. 65706631, 2009.

[29] J. S. Valente, F. Tzompantzi, and J. Prince, "Highly efficient photocatalytic elimination of phenol and chlorinated phenols by $\mathrm{CeO}_{2} / \mathrm{MgAl}$ layered double hydroxides," Applied Catalysis B: Environmental, vol. 102, no. 1-2, pp. 276-285, 2011.

[30] J. C. Garcia, J. L. Oliveira, A. E. C. Silva, C. C. Oliveira, J. Nozaki, and N. E. de Souza, "Comparative study of the degradation of real textile effluents by photocatalytic reactions involving $\mathrm{UV} / \mathrm{TiO}_{2} / \mathrm{H}_{2} \mathrm{O}_{2}$ and $\mathrm{UV} / \mathrm{Fe}^{2+} / \mathrm{H}_{2} \mathrm{O}_{2}$ systems," Journal of Hazardous Materials, vol. 147, no. 1-2, pp. 105-110, 2007. 

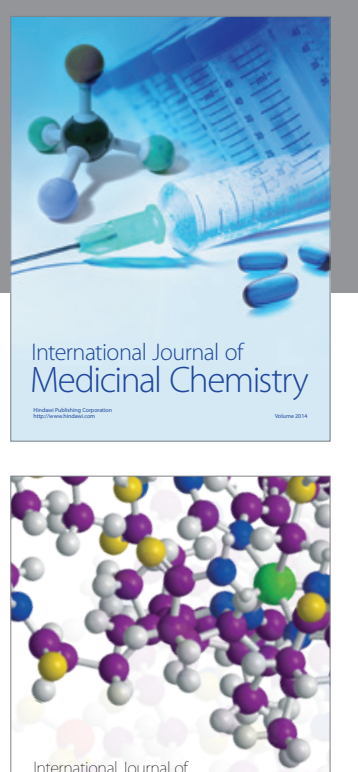

Carbohydrate Chemistry

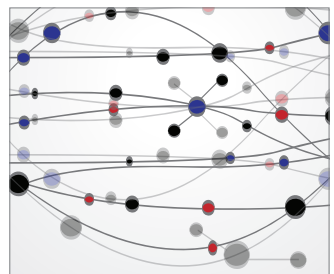

The Scientific World Journal
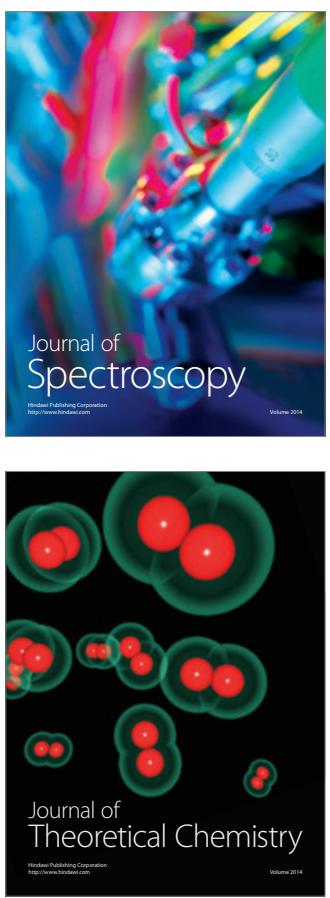
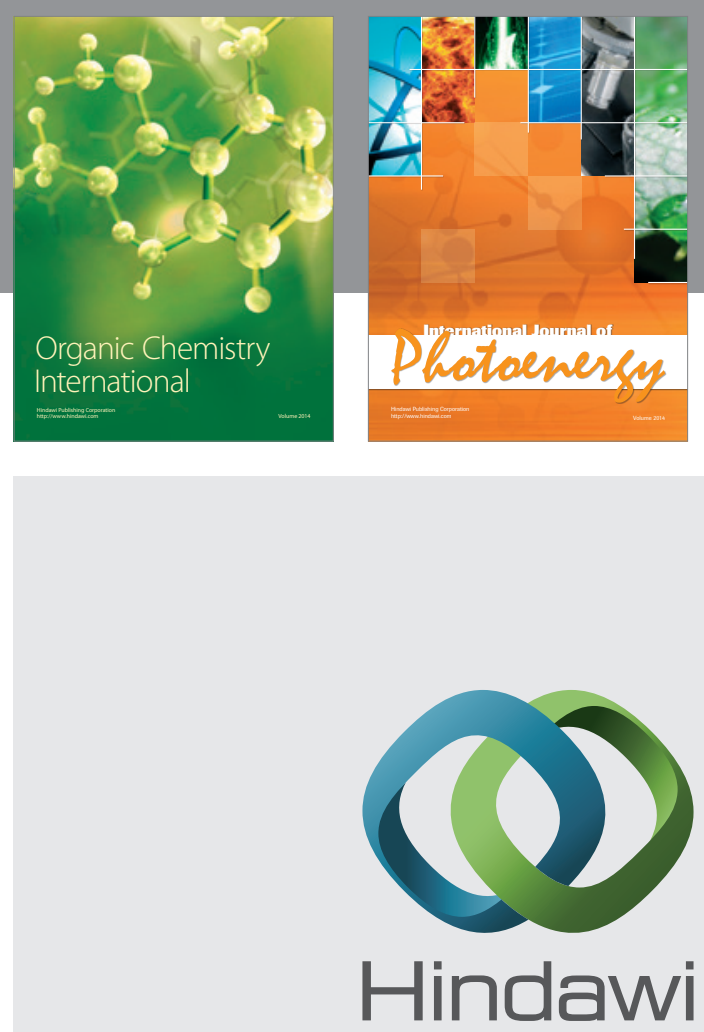

Submit your manuscripts at

http://www.hindawi.com

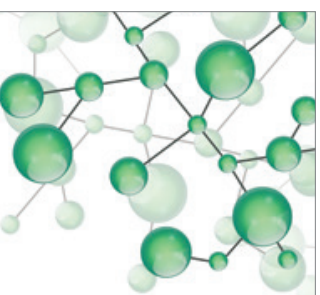

International Journal of

Inorganic Chemistry

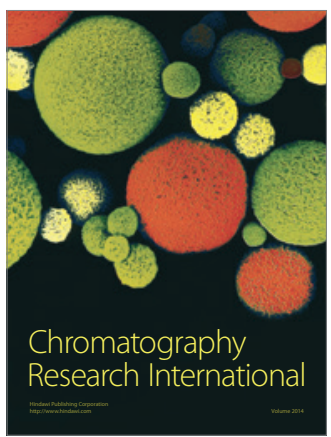

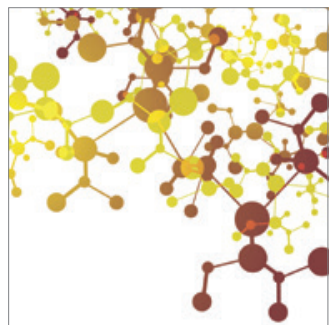

Applied Chemistry
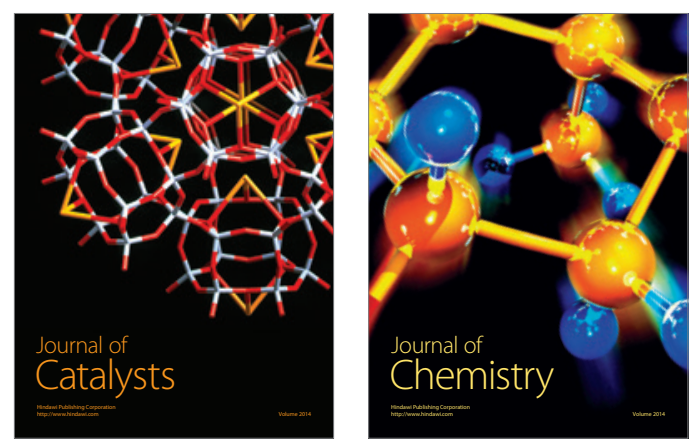
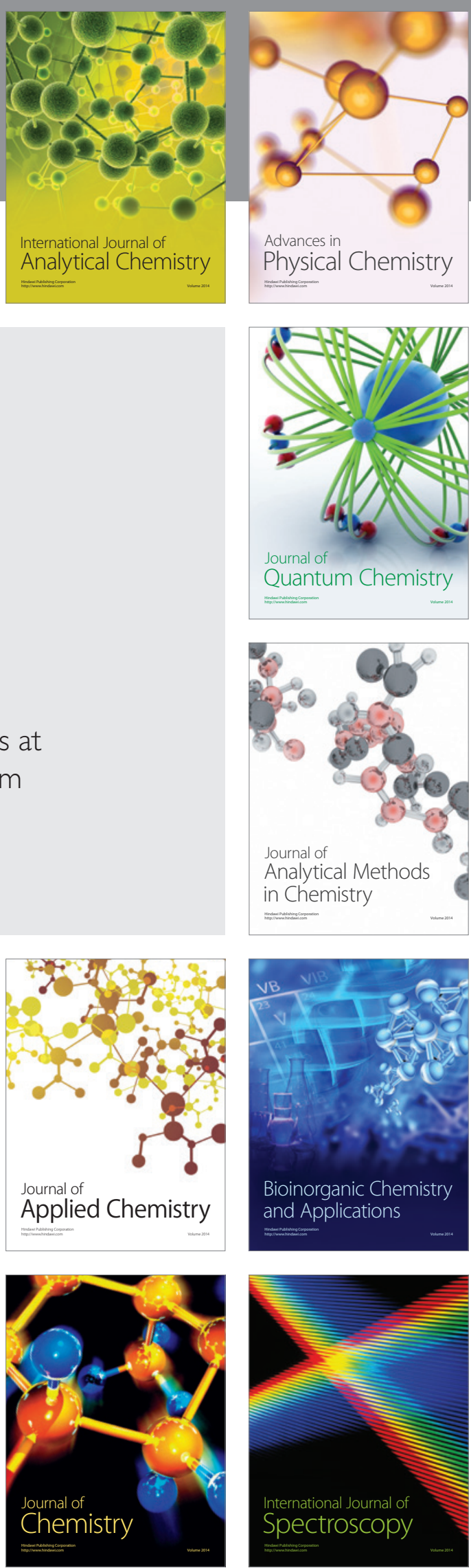